УДК 821.133.1-311.6.09

DOI https://doi.org/10.26661/2414-9594-2021-1-32

\title{
ДІАЛЕКТИКА РОЗВИТКУ ГРУПОВОЇ ТА ЕГО-ІДЕНТИЧНОСТІ В РОМАНІ А. ФРАНСА «БОГИ ЖАДАЮТЬ»
}

\author{
Динниченко Т. А. \\ кандидат філологічних наук, \\ старший викладач кафедри світової літератури \\ Київський університет імені Бориса Грінченка \\ вул. Маршала Тимошенка, 13-Б, Київ, Украӥна \\ orcid.org/0000-0003-0446-7743 \\ t.dynnychenko@kubg.edu.ua
}

Ключові слова: психоаналіз, механізм ідентифікації, підсвідомість, механізм ідеалізаиії, «Ідеал-Я», об'єктідеал, сновидіння совісті.
Стаття присвячена дослідженню особливостей репрезентації в романі А. Франса «Боги жадають» процесу формування i розвитку егоідентичності головного героя у складному взаємозв'язку з колективною ідентичністю. У розвідці застосований психоаналітичний підхід до аналізу художнього тексту. Поведінка, думки, почуття персонажа інтерпретуються крізь призму психоаналізу 3 використанням таких термінів 3. Фройда, К.Г. Юнга, А. Адлера, Е. Фромма, як «підсвідомість», «ідентифікація», «внутрішній конфлікт», «Ідеал-Я», «зовнішній об’єкт-ідеал», «психічний механізм ідеалізації», «сновидіння совісті», «архетип» тощо. Дослідження побудоване на поняттях колективної й егоідентичності, уведених у науковий обіг Еріком Г. Еріксоном. Цей відомий культуролог і психолог аргументовано пов'язує формування особистої ідентичності із груповою. Різноманітні аспекти проблеми ідентичності $€$ пріоритетними в європейській літературі початку ХХ століття.

У романі А. Франса «Боги жадають» зображується момент кардинального змінення колективної ідентичності французького суспільства внаслідок великої історичної події - революції 1789-1794 років. Автор показує механізм ідентифікації в дії: як утверджуються нові соціальні й культурні цінності, як відбувається соціальна спайка, як усе це впливає на свідомість окремих індивідів. У центрі твору - психодрама молодого художника Еваріста Гамлена. Його его-ідентичність, внутрішнє «Ідеал-Я» доброчесної, стриманої людини формувалися до революції в конфлікті із груповою, що виявлялося в характері, поведінці, професійній діяльності. Республіканська групова ідентичність спочатку сприяє розвитку його особистої ідентичності, але пристрасне захоплення революційними лідерами запускає психічний механізм ідеалізації, що призводить до несвідомої підміни внутрішнього «Ідеал-Я» зовнішнім об'єкт-ідеалом i втрати власного «Я». А. Франс візуалізує конфлікт у підсвідомості свого героя, який виникає внаслідок такого патологічного процесу підміни, за допомогою алюзії на трагедію Еврипіда «Орест». Паралель Еваріст / Орест виявляє подібність психічного стану персонажів - обох мучить «неусвідомлена» совість через вчинки, які вони внутрішньо визнають злом, хоча свідомо виправдовують «священним велінням». Аналіз тексту роману «Боги жадають» із психоаналітичних позицій виявляе, що сюжет можна інтерпретувати як художнє дослідження розвитку его-ідентичності головного персонажа в діалектичному зв'язку з колективною ідентичністю. 


\title{
THE DIALECTICS OF THE DEVELOPMENT OF GROUP AND EGO-IDENTITY IN A. FRANCE'S NOVEL "THE GODS ARE ATHIRST"
}

\author{
Dynnychenko T. A. \\ Candidate of Philological Sciences, \\ Senior Lecturer at the Department of Foreign Literature \\ Borys Grinchenko Kyiv University \\ Marshala Tymoshenka str., 13-B, Kyiv, Ukraine \\ orcid.org/0000-0003-0446-7743 \\ t.dynnychenko@kubg.edu.ua
}

Key words: psychoanalysis, mechanism of identification, subconscious, mechanism of idealization, "Ideal-I", objectideal, dreams of conscience.
The article is devoted to the study of the peculiarities of representation in the novel by A. France "The Gods are Athirst" the process of formation and development of the ego-identity of the protagonist in a complex relationship with the collective identity. Psychoanalytic approach to the analysis of a literary text is used in intelligence. Behavior, thoughts, feelings of the character are interpreted through the prism of psychoanalysis using such terms S. Freud, K.G. Jung, A. Adler, E. Fromm, as the "subconscious", "identification", "internal conflict", "Ideal-I", "external object-ideal", "mental mechanism of idealization", "dreams of conscience", "archetype", etc. The study is based on the concepts of collective and ego-identity, introduced into scientific circulation by Eric G. Erickson. This well-known culturologist and psychologist argues that the formation of personal identity with the group. Various aspects of the problem of identity are a priority in the European literature of the early twentieth century.

A. France's novel "The Gods are Athirst" depicts a moment of radical change in the collective identity of French society as a result of a great historical event - the revolution of 1789-1794. The author shows the mechanism of identification in action: how new social and cultural values are established, how it affects the consciousness of individuals. At the center of the work is a psychodrama by the young artist Evarist Hamlen. His ego-identity, the inner "Ideal-I" of a virtuous, restrained man were formed before the revolution in conflict with the group, which manifested itself in character, behavior, professional activity. The republican group identity initially promotes the development of his personal identity, but the passionate fascination with revolutionary leaders triggers a mental mechanism of idealization, which leads to the unconscious replacement of the inner "Ideal-I" by an external object-ideal and the loss of one's own "I". And France visualizes the conflict in the subconscious of his hero, which arises as a result of such a pathological process of substitution, with an allusion to the tragedy of Euripides "Orestes". The Evarist / Orestes parallel reveals the similarity of the mental state of the characters - both are tormented by an "unconscious" conscience because of actions that they internally recognize as evil, although they consciously justify it by "sacred command". An analysis of the text of the novel "The Gods are Athirst" from a psychoanalytic standpoint proves that the plot is constructed as a study of the development of the main character's ego-identity in a dialectical connection with the collective identity.
У сучасному літературознавстві поняття ідентичності / ідентифікації є полем різноманітних досліджень. Мета цієї розвідки - аналіз репрезентації складного процесу формування его-ідентичності в романі А. Франса «Боги жадають» крізь призму психоаналізу. Психоаналітичне літературознавство є невід'ємною скла- довою частиною сучасної вітчизняної науки про літературу, про що свідчать грунтовні наукові студії Н. Зборовської, А. Печарського, О. Бідюк, О. Тиховської, О. Вертипорох, Ю. Кузнецова й інших. Психоаналітичний підхід до аналізу зазначеного роману А. Франса не застосовувався, проте він дає змогу дослідити його глибинні аспекти. 
Автором за даної розвідки вже опублікував статті «Алгоритм дії колективного неусвідомленого в романі А. Франса «Боги жадають»» (2017р.), «Архетипна складова в художньому світі роману А. Франса «Боги жадають»» (2018р.), «Метафоричне моделювання психічного розладу в романі А. Франса «Боги жадають»» (2020р.).

У класичному психоаналізі ідентифікація визначається як «ранній прояв емоційного зв'язку людини з іншою. Завдяки цьому процесові відбувається формування власного Я, узятого за взірець наслідування» $[1$, с. 61]. 3. Фройд пов'язував $з$ ідентифікацією, амбівалентною за своєю природою, появу «комплексу Едіпа» у дитини; К.Г. Юнг - поняття «народ» і «колективне неусвідомлюване»; А. Фройд - самозахист «Я» індивіда. Автор концепції «гуманістичного психоаналізу» Е. Фромм, відкидаючи біологізм 3. Фройда, уважав ідентифікацію одним із психологічних механізмів, що несвідомо утворюються під час переходу людини до соціальної історії і регулюють відносини індивіда зі світом, уживав термін «автоматичний конформізм» - «знищення свого «Я» завдяки ідентичності 3 мільйонами інших» [2, с. 172].

Ми бачимо різнобічний підхід до витлумачення поняття «ідентифікація», змішування індивідуальної і групової ідентичності. Спробу об'єднати всі ці аспекти здійснив культуролог і психолог Ерік Г. Еріксон: він уважав процес ідентифікації одним iз культурних механізмів виживання, запропонував розрізняти два іiі рівні - групову ідентичність і особисту (его-ідентичність). Групова ідентичність формується з народження людини: з одного боку, індивід сприймає життєвий приклад певної групи, яка є його соціальним середовищем, 3 іншого ця група прийнятими в ній методами виховання нав'язує йому якісь погляди й поведінку. Одним із найважливіших інструментів формування групової ідентичності дослідник уважав ритуал - «історично сформовану форму складної символічної поведінки, що виражає певні соціальні й культурні цінності» [Цит. за: 3, с. 149].

Формування его-ідентичності йде паралельно формуванню групової і нерозривно пов'язано 3 нею. Е.Г. Еріксон підкреслює основоположну роль групової ідентичності в цьому процесі, розглядає життя людини як ряд послідовних ступенів інтеграції, «включення соціальних цінностей в его» [Цит. за: 3, с. 148]. У розвиненому суспільстві формування его-ідентичності стає головною метою розвитку особистості, залежно від індивідуальних характеристик, відбувається в унісон із груповою ідентичністю або в конфлікті з нею. У процесі ідентифікації поступово формується власне «Ідеал-Я» особистості, яке й визначає внутрішне відчуття гармонії чи дисгармонії із соціумом.
Різноманітні варіанти складних відносин колективної й особистої ідентичностей є предметом зображення в багатьох модерністських твоpax. Серед них роман А. Франса «Боги жадають», у якому на матеріалі подій Французької революції 1789-1794 рр. описується формування нової колективної ідентичності в період «болісного переходу від однієї моделі нації до іншої» [4, с. 5]. Письменник майстерно візуалізує «швидке перенесення сакральності 3 монархічного на національне, з релігійного на політичне» [4, с. 158]: у приміщеннях церков, зайнятих республіканськими установами, «< ..> релігійні емблеми було збито, а натомість над дверима виведено чорними літерами республіканський девіз: «Свобода, Рівність, Братерство - або смерть»»; замість святих - «погруддя Брута, Жан-Жака та Лепелетьє. На обдертому вівтарі височіла таблиця з Декларацією прав людини», а «за трибуну промовцям правила кафедра, прикрашена національними прапорами» $[5$, с. 355$]$.

Перед керманичами новоствореної республіки стоїть мета формування «республіканської духовності», тобто утвердження нових соціальних i культурних цінностей через нові ритуали [4, с. 159]. I вони вміло поєднують звичні французькому народові форми 3 новим політичним змістом: організують масові видовищні громадські свята 3 ярмарками й гулянням між величезними алегоричними скульптурами, як-от «народ-Геркулес, що розмахує палицею» [5, с. 410], влаштовують публічні суди над ідейними єретиками і привселюдне їх покарання на гільйотині (як колись спалювали відьом на Гревській площі).

Особливе значення серед нових ритуалів має урочиста хода революційних лідерів (Марат виходить до людей у «вінку з дубового листя» [5, с. 385], Максімільєн - «3 букетом колосків, волошок і маку в руці» [5, с. 505], а жінки кидають їм квіти), яка мають на меті викликати в народу нумінозні почуття до вождів. Такі почуття $\epsilon$ найважливішим чинником утворення між членами нової держави «соціальної спайки», заснованої на механізмі ідентифікації: коли всі члени суспільства «переносять своє «Ідеал-Я» на той самий об'єкт, їм не залишається нічого іншого, як взаємоототожнитися, стати рівними один одному, нівелювати свої відмінності» [6, с. 309].

Формування нової колективної ідентичності відбувається на амбівалентній основі - любові до Республіки, яка проголошує демократичні гасла, й ненависті до монархії, де привілеї належали аристократам. Отже, засуджуються пишнота, марнотратство й розпуста, натомість стверджуються нові республіканські чесноти - простота, стриманість, доброчесність, а найвищою 3 них $\epsilon$ любов до батьківщини. В умовах загрози 
Республіці з боку численних ворогів гасло патріотизму активує потужний колективний архетип Аніми, могутність якого в усіх народів утілена в образі Матері-Вітчизни: «Знаючи напевно, що загибель вітчизни - це водночас і їхня власна загибель, вони порятунок вітчизни вважали своєю кровною справою. Отже, інтереси нації, поєднані 3 інтересами особистими, визначали почуття, пристрасті, поведінку» [5, с. 451]. Нова форма звернення - «громадянин/громадянка» - унаочнює ідентичність членів нової спільноти.

А. Франс у романі «Боги жадають» репрезентує складність діалектичного зв'язку розвитку колективної й особистої ідентичностей. Головний герой, художник Еваріст Гамлен, до революції відчужувався від соціуму: не поділяв моралі та смаків, що панували в останній третині XVIII ст. у Франції. 3 дитинства його его-ідентичність розвивалася в конфлікті із груповою, адже він за своєю природою був цнотливим і доброчесним, прагнув до простоти і стриманості: ще хлопчиком він «статечно йшов вулицею і повторював сам до себе катехізис» [5, с. 366]. У дорослому віці цей дисонанс між особистою та груповою ідентичністю виразно виявлявся у професійній діяльності: манера рококо «аж ніяк не пасувала до його вдачі», усі написані за модою «любовні сцени» були «трактовані з холодним серцем» [5, с. 361].

Проте Гамлен не відчував провини за свою не-ідентичність, а вважав іiї за чесноту: таким способом він відділяв себе від неправедних, недоброчесних. А. Адлер зауважує, що будь-який індивід, «пристосовуючись до реальності», «відчуватиме й оцінюватиме досягнуту ним позицію» у суспільстві «залежно від того... у чому знаходить свою кінцеву мету, - бачить він себе - у своїх дитячих фантазіях $<\ldots>$ - у ролі кучера, коня, генерала, лікаря чи рятівника людства» [7, с. 135]. Так, Еваріст, вочевидь, бачив себе суддею: відчуття своєї відмінності дорівнювало відчуттю кращості, а власна бездоганність немовби давала йому право судити. Власне «Ідеал-Я» цього персонажу до революції - «порядна людина», яка вірить у «принципи природної моралі» і може «знаходити в собі самій джерела справедливості і правила доброчесного життя» [5, с. 456].

Революція утвердила нові колективні ціннісні орієнтири: тепер вони цілковито відповідали природі й переконанням Еваріста, унаслідок чого змінилося і його самовідчуття в соціумі: він був уже не маргіналом, а «добрим громадянином» [5, с. 386]. Спочатку це посприяло швидкому подальшому розвитку його его-ідентичності, надавши його «здебільшого невиразним і шляхетним думкам» [5, с. 384] конкретності та дієвості. Гамлен-художник ідентифікує себе як учня Давіда - законодавця нового мистецтва, «просякнутого пафосом патрі- отичного обов'язку», яке утверджувало «високі громадянські й особисті чесноти» [8, с. 195], i 3 пристрасним захопленням малює монументальні «образи Свободи, Прав Людини, французьких Конституцій, республіканських чеснот, народних Гераклів, що долають гідру Тиранії» $[5$, c. 362].

Проте художньої діяльності виявляється замало, щоб наситити душу Еваріста, яка «прагнула великих звершень» [5, с. 363]. Гамлен жадає власноруч розбудовувати новій світ, який постає в його уяві в образі «мідної Діке, міста справедливості» [5, с. 378]. Цей образ є символічним для визначення вектора подальшого розвитку его-ідентичності цього персонажа, адже в давньогрецькій міфології богиня Діке - утілення справедливості - була дочкою Зевса-громовержця і богині правосуддя Феміди. Автор підкреслює, що Гамлен $є$ «схильним від природи й підготовленим літературним вихованням до ролі домашнього судді», який без вагань «із властивою йому суворістю засудив сестру і ладен був засудити і свою кохану» [5, с. 387].

Гамлен отримує посаду присяжного судді у Трибуналі, яка нібито якнайбільше відповідала його внутрішній сутності, проте вона стає фатальною для розвитку його его-ідентичності. Психологи зауважують, що особистістю можна вважати лише «людину, яка свідомо ставиться до своєї діяльності» [Цит. за: 3, с. 30]. I на початку Еваріст-суддя, відчуваючи свою відповідальність, ретельно зважує аргументи обвинувачення й захисту, радіє, коли йому вдається "розпізнати безвинного» [5, с. 445]. Підтримка народу ще більше окрилює його і сповнює відчуття виконаного обов'язку: «Як приємно бути доброчесним i яка солодка серцю непідкупного судді вдячність суспільства» $[5$, с. 501$]$.

Але поступово все змінюється, Гамлен, який завжди вважав себе «від природи людиною чулою і ніжною», із «чесним серцем», перетворюється на безжального ката, що «не знає ні приятеля, ні ворога» [5, с. 420]. Вступаючи на посаду, він заприсягається «в ім'я священної людськості заглушити у своїй душі всі людські слабкості» [5, с. 419], і справді втрачає притаманні йому від природи співчуття, милосердя, правдолюбство. Сам Еваріст упевнений, що піднявся «над усіма пристрастями» [5, с. 508] і перетворився на чистий голос правди. Проте, насправді, він тепер керується не мораллю, а ідеологією, і «незмінно подає голос за смерть» [5, с. 456], переконаний, що це «конче потрібно для порятунку нації» [5, с. 513]. Поступово в його уяві покарання перетворюється «на якусь релігійну, містичну ідею» [5, с. 453]: він готовий, відкинувши «злочинні жалощі», рятувати Францію «усупереч їй самій», і навіть 
«коли вона благає милосердя, затуляти собі вуха і рубати» [5, с. 517].

Такі дії та образ мислення суперечать внутрішньому єству цього «переконаного прихильника свободи сумління» $[5$, с. 456$]$ і докорінно розходяться зі сформованим раніше власним «Ідеал-Я». Це пояснюється дією психічного механізму ідеалізації, «протилежного утворенню «Ідеал-Я», коли ми не «вбираємо в себе об'єкт, збагачуючи ним свою душу», а навпаки, «вкладаємо в об' єкт частину себе самого, саме своє «Ідеал-Я»», «збагачуємо об'єкт, збіднюючи себе» [6, с. 309]. Гамлен занадто ідеалізує революційних лідерів, «великих громадян», тому що бачить у «непідкупно чесному» Робесп'єрі, «Другові Народу» Мараті 3 його «безжалісною любов'ю», «пильному» Максімільєні лише ті якості, які близькі його «Ідеал-Я». Поступово вони перетворюються для нього на уособлення всіх громадянських i людських чеснот, згодом створений ним ідеал він несвідомо ототожнює із власним «Ідеал-Я», що призводить до втрати власного «Я».

У таких випадках зовнішній ідеал стає для особистості «ії внутрішнім переконанням, установчим чинником поведінки <..> Переконання виступає внутрішнім Я, повертаючись у сферу підсвідомості» [9, с. 124], і займає місце ії совісті. Саме тому заклики вождів сприймаються Гамленом як веління власного серця, його розум позбавляється будь-яких сумнівів, а душа - докорів сумління. Відбувається цілковите відчуження Гамлена від свого реального «Я»: тепер вбиває не він і вбиває не людей - це Республіка знищує своїх ворогів. Заміна внутрішнього «Ідеал-Я» зовнішнім - це, за визначенням психологів, патологічний процес, який призводить до зникнення «певної частини психіки», до «втрати душі» [10, c. 157].

Алюзія на трагедію Еврипіда «Орест» відіграє, як уже зазначалося дослідниками, важливу роль у романі «Боги жадають». У контексті нашого дослідження ми інтерпретуємо іiі як художній засіб, який дозволяє письменникові показати патологічну сутність процесу заміни внутрішнього «Ідеал-Я» зовнішнім. Еваріст в А. Франса нібито докорінно відрізняється від героя Еврипідової трагедії, бо його образ позбавлений внутрішнього конфлікту: так, Орест змушений учинити вбивство, божеволіє через це, а Еваріст вбиває безперестанку і зовсім не переживає. Проте автор через цю алюзію унаочнює подібність психічного стану цих персонажів.

А. Франс доводить, що чинники їхніх дій мають однакову природу: Орест вбиває рідну матір за велінням бога Аполлона, а Еваріст вбиває співвітчизників за велінням вождів, яких сприймає як богів; Ореста спонукає до злочину синівська любов до батька, а Еваріста - синівська любов до батьківщини; Орест здійснює вбивство заради встановлення справедливості, Еваріст - заради святої ідеї справедливого устрою («щоб завтра всі французи обнялися, заливаючися сльозами радості» $[5$, с. 519$])$.

Автор демонструє також схожість наслідків: Орест, виконуючи волю богів, «нехтує закони природи», тому не знає спокою: плаче уві сні, «зривається з постілі, наче кінь, що збив ярмо» [Еврипід]; Еваріст, виконуючи директиви керманичів, нібито легко переміг «природні почуття» [5, с. 508], але «разів по двадцять на ніч схоплювався, переслідуваний кошмарами» [5, с. 509]; Орест почувається «відлученим від усіх» [11], Еваріст - самотнім серед людей, бо «поставив себе поза людством» [5, с. 517-518].

Отже, А. Франс за допомогою алюзії на образ Ореста візуалізує неусвідомлений внутрішній конфлікт Гамлена. Хоча Еваріст стверджує, що, як присяжний, радиться «тільки зі своїм сумлінням» [5, с. 419], насправді діє всупереч йому і мучиться через це уві сні. Це цілком співвідноситься із фройдівським поняттям неусвідомленої совісті: саме вона породжує так звані сновидіння совісті, коли людина вчиняє те, що підсвідомо визнає злом.

Отже, психоаналітичний підхід до аналізу роману «Боги жадають» дозволяє проінтерпретувати його сюжет як зображення динамічного i складного розвитку его-ідентичності головного персонажа в діалектичному зв'язку з колективною ідентичністю. Логіка розвитку дії твору побудована за логікою складного процесу самоідентифікації Еваріста Гамлена: від протиставлення власної его-ідентичності колективній ідентичності у старому соціумі, через їх гармонізацію в новому, і до заміщення власного «Ідеал-Я» зовнішнім об'єкт-ідеалом, що призводить до руйнації його особистості. Застосування психоаналітичної методики дослідження тексту допомагає виявити причину, яка призвела до патологічної трансформації головного героя роману, - це втрата власного «Я» унаслідок дії психічного механізму ідеалізації.

\section{ЛІТЕРАТУРА}

1. Печарський А. Психоаналітичний аспект української белетристики першої третини XX ст. : монографія. Львів : ЛНУ імені Івана Франка, 2011. 466 с.

2. Фромм Э. Автоматический конформизм. История зарубежной психологии (30-60-е гг. XX в.) : тексты / под ред. Г. Ливанова. Москва : Издательство Московского университета, 1986. С. 171-185.

3. Левчук Л. Психоанализ: от бессознательного к «усталости от сознания». Киев : Вища школа, 1989. 183 с. 
4. Нора П. Теперішнє, нація, пам’ять. Київ : ТОВ «Видавництво «Кліо»», 2014. 272 с.

5. Франс А. Боги жадають. Твори : у 5-ти т. / А. Франс. Київ : Дніпро, 1977. Т. 4. С. 353-536.

6. Волошинов В. Фрейдизм. Психоанализ и русская мысль / / Зигмунд Фрейд ; под ред. В. Лейбина. Москва : Республика, 1994. С. 269-346.

7. Адлер А. Индивидуальная психология. История зарубежной психологии (30-60-е г2. XX в.) : тексты / под ред. П. Гальперина, А. Ждан. Москва : Издательство Московского университета, 1986. С. $131-140$.

8. Наливайко Д. Искусство, направления, стили. Киев : Мистецтво, 1980. 288 с.

9. Панов В. Эмоции. Мифы. Разум. Москва : Высшая школа, 1992. 252 с.

10. Юнг К.Г. Аналитическая психология. История зарубежной психологии (30-60-е г2. XX в.) : тексты / под ред. П. Гальперина, А. Ждан. Москва : Издательство Московского университета, 1986. С. $142-170$.

11. Еврипид Орест. URL: https://libking.ru/books/poetry-/poetry/16001-evripid-orest.html.

\section{REFERENCES}

1. Pecharskii A. (2011) Psikhoanalitichnii aspekt ukrayins'koyi beletristiki pershoyi tretini XX storichchya [Psychoanalytic aspect of Ukrainian fiction of the first third of the XX century]. Lviv: LNU imeni Ivana Franka. (in Ukranian)

2. Fromm E. (1986) Avtomaticheskii konformizm [Automatic conformism]. In G.S. Livanova (Ed.), Istoriya zarubezhnoi psikhologii (30-60-e gg. XX v.). [History of foreign psychology (30-60-ies of the XX century)] M.: Moscow University. pp. 171-185 (in Russian)

3. Levchuk L.T. (1989) Psikhoanaliz: ot bessoznatel'nogo k "ustalosti ot soznaniya" [Psychoanalysis: from the unconscious to "consciousness fatigue"]. K.: Vyshcha shkola. (in Russian)

4. Nora P. (2014) Teperishne, natsiya, pamyat' [Present, nation, memory] K.: TOV "Vidavnitstvo "KLIO"”. (in Ukranian)

5. Frans A. (1977) Bogi zhadayut' [The Gods Are Athirst]. Anatol' France. Tvori v Pyati tomakh [Anatole France. Works in five volumes] (Vol. 4). K: Dnipro. pp. 353-536 (in Ukranian)

6. Voloshinov V.N. (1994) Freidizm [Freudianism]. Sigmund Freid. Psichoanalis i russkaya mysl' [Sigmund Freud. Psychoanalysis and Russian thought]. M.: Republic. pp. 294-346 (in Russian)

7. Adler A. (1986) Individual'naya psikhologiya [Individual psychology.] In P.Y. Gal'perin, A. N. Zhdan. (Ed.). Istoriya zarubezhnoi psikhologii (30-60-e gg. XX v.) [History of foreign psychology (30-60-ies of the XX century)]. M.: Moscow University. pp. 131-140 (in Russian)

8. Nalivaiko D.S. (1980) Iskusstvo, napravleniya, stili [Art, directions, styles]. - K.: Mistetstvo. (in Russian)

9. Panov V.G. (1992) Emotsii. Mify. Razum [Emotions. Myths. Intellect]. M.: Vysshaya shkola. (in Russian)

10. Yung K.G. Analiticheskaya psikhologiya [Analytical psychology]. In P. Y. Gal'perin, A.N. Zhdan. (Ed.). Istoriya zarubezhnoi psikhologii (30-60-e gg. XX v.) [History of foreign psychology (30-60-ies of the $X X$ century)]. M.: Moscow University. pp. 142-170 (in Russian)

11. Euripides Orest [Orestes] [Product innovative policy] Retrieved from: https://libking.ru/books/poetry-/ poetry/16001-evripid-orest.html. 